\title{
Evaluation of the Relationship Between ARID1A Expression with Clinicopathologic Parameters in Gastric Carcinomas
}

Özgün Araştırma Research Article
Alındığı tarih: 14.11 .2018 Kabul tarihi: 15.01.2019 Online Yayın tarihi: 31.12 .2019

Elif Usturalı Keskin Trakya Üniversitesi Tıp Fakültesi Patoloji Anabilim Dalı, Merkez Edirne - Türkiye drelifkeskin@gmail.com ORCID: 0000-0003-0656-2576

G. Diniz 0000-0003-1512-7584

Y. Koca 0000-0002-7404-3877

S. Eryigit Kokkoz 0000-0003-0276-7080

E. Çakır 0000-0001-7959-3491

SBÜ. İzmir Tepecik Eğitim Araştırma Hastanesi, Tıbbi Patoloji Bölümü, İmir, Türkiye

A.N. Usturalı Mut 0000-0002-6832-8067 Ankara Üniversitesi Tıp Fakültesi Halk Sağlığı Ana Bilim Dalı, Ankara, Türkiye

Cite as: Usturalı Keskin E, Diniz G, Usturalı Mu Cite as: Usturalı Keskin E, Diniz G, Usturalı Mut
AN, Koca Y, Eryigit Kokkoz S, Çakır E. Evaluation of the relationship between ARID1A expression with clinicopathologic parameters in gastric carcinomas. Tepecik Eğit. ve Arașt. Hast. Dergisi. 2019;29(3):273-9.

\section{Mide Karsinomlarında ARID1A Ekspresyonunun Klinikopatolojik Parametrelerle Illişkisinin Araştırılması}

\author{
Elif Usturalı Keskin $\odot$, Gülden Diniz $\oplus$, Ayşe Nur Usturalı Mut $\odot$, Yetkin Koca $\odot$, \\ Seda Eryiğit Kokkoz $\oplus$, Ebru Çakır $\odot$
}

\begin{abstract}
Objective: Development of gastric carcinoma is regulated by many factors. Adenine-thymine rich interactive domain $1 A(A R I D 1 A)$ is a tumour suppressor gene involved in chromatin remodeling and it encodes the ARID1A protein. Recent studies have shown the loss of ARID1A expression in gastric carcinomas may have a prognostic significance. In our study, we investigated the possible prognostic role of ARID1A loss in gastric carcinomas.

Method: We investigated ARID1A expression in 113 formalin-fixed, paraffin-embedded gastric carcinoma specimens and its association with different pathological and clinical parameters.

Results: The mean percentage of ARID1A-stained cells was 55.42\% (min 1\%, and max 100\%). ARID1A expression was found in pT1b (73.89\%), pT254 (22\%), pT353 (76\%) and pT4 (53.92\%) tumours ( $p=0.219)$. ARID1A expression was found in poorly cohesive (56.61\%), tubular (48.52\%), mucinous (80\%), papillary (73.75\%) and mixed type (76.25\%) tumours ( $p=0.093)$. ARID1A expression was found in HER2-positive $(61.23 \%)$ and HER2-negative (53.22\%) tumours $(p=0.262)$. ARID1A expression was evaluated and compared with tumour localisation and other pathological parameters as lymph node metastasis, perineuronal invasion, lymphovascular invasion, and any statistically significant difference was not found between both groups. Contrarily, there was a significant association between ARID1A expression and survival of HER 2 negative tumors $(p=0.047)$.

Conclusion: Identification of specific biomarkers is very important for prediction of clinical outcome in gastric tumours. We demonstrated loss of ARID1A expression in HER2-negative gastric carcinomas positively correlated with overall survival. These results suggest that ARID1A may play a role in the biology of HER2-negative gastric carcinomas.
\end{abstract}

Keywords: Gastric carcinoma, ARID1A, HER2

Öz

Amaç: Gastrik karsinom gelişimi birçok faktörle düzenlenir. Adenin Timinden zengin interaktif domain 1A (ARID1A) kromatin remodelizasyonunda yer alan tümör supresor gendir ve ARID1A proteinini kodlar. Yakın zamanda yapılan çalışmalar ARID1A ekspresyon kaybının gastrik karsinomlarda prognostik önemi olduğunu göstermiştir. Çalışmamızda, mide karsinomlarında ARID1A kaybının muhtemel prognostik rolünü araştırdık.

Yöntem: Formalinde fikse edilmiş, 113 parafinize gastrik karsinom spesmeninde ARID1A ekspresyonu ve bunun farklı klinikopatolojik parametrelerle ilişkisi araştırıldı.

Bulgular: ARID1A boyanan hücrelerin ortalama yüzdesi $\% 55,42$ (minimum=1\%, maximum=100\%) idi. ARID1A ekspresyonu pT1b tümörlerde \%73,89, pT2 tümörlerde \%54,22, pT3 tümörlerde \%53,76, pT4 tümörlerde \%53,92 bulundu ( $p=0,219)$. ARID1A ekspresyonu az koheziv tip tümörlerde ortalama \%56,61, tübüler tipte \%48,52, müsinöz tipte $\% 80$, papiller tipte $\% 73,75$ ve mikst tipte $\% 76,25$ bulundu $(p=0,093)$. ARID1A ekspresyonu HER2 pozitif tmörlerde \%61,23 ve HER2 negatif tümörlerde $\% 53,22$ bulundu ( $p=0,262)$. ARID1A ekspresyonu ile tümör lokalizasyonu, lenf nodu metastazı, perinöral invazyon lenfovasküler invazyon gibi klinikopatolojik parametreler karşılaştırıldı ama istatistiksel olarak anlamlı değildi. Karşıt olarak ARID1A ekspresyonu ve HER2 negatif tümörlerin sağkalımı arasında istatistiksel olarak anlamlı ilişki vardı $(p=0,047)$.

Sonuç: Mide tümörlerinde klinik gidişi tahmin etmede spesifik biyomarkerların tanımlanması çok önemlidir. Biz HER2 negatif mide karsinomlarında ARID1A ekspresyon kaybının sağ kalım ile doğru korele olduğunu bulduk. Bu sonuçlar ARID1A nın HER2 negatif mide karsinomlarının biyolojisinde bir rol oynayabileceğini göstermektedir.

Anahtar kelimeler: Gastrik karsinom, ARID1A, HER2
(C) Telif hakkı T.C. Sağık Bakanlığı İmir Tepecik Eğit. ve Araşt. Hastanesi. Logos Tıp Yayıncılık tarafindan yayınlanmaktadır. Bu dergide yayınlanan bütün makaleler Creative Commons Atff-GayriTicari 4.0 Uluslararası Lisansı ile lisanslanmıştır.

(c) Copyright Association of Publication of the T.C. Ministry of Health Izmir Tepecik Education and Research Hospital. This journal published by Logos Medical Publishing. Licenced by Creative Commons Attribution-NonCommercial 4.0 International (CC BY-NC 4.0) 


\section{INTRODUCTION}

Gastric carcinomas rank second among the most frequently seen life-threatening cancers in the world. Since at the time of diagnosis $90 \%$ of them are in their advanced stages, their survival rates are very low. Interactions among individual factors such as diet, Helicobacter pylori (HP) infection, environmental factors, and genetic predisposition lead to the development of gastric carcinoma ${ }^{(1-4)}$. Correa's gastric carcinogenesis cascade accepted by many investigators starts with HP infection, and follows a course passing through the stages of superficial gastritis, chronic atrophic gastritis, intestinal metaplasia, dysplasia, and finally gastric carcinoma ${ }^{(5,6)}$.

HER2 (Human epidermal growth factor receptor 2) amplification results in one of the intrinsic subtypes of gastric carcinomas with specific phenotypes ${ }^{(7,8)}$. In gastric carcinoma HER2 amplification is a negative prognostic factor ${ }^{(7,8)}$.

The AT-rich interactive domain 1 alpha (ARID1A) protein, which is encoded by ARID1A gene, is a subunit of chromatin remodeler Switch/Sucrose Nonfermentable (SWI/SNF) complex ${ }^{(9)}$. Mutation of ARID1A causes several differentiations in the expression of multiple genes via dysfunction of chromatin remodeling ${ }^{(10)}$. It has been shown that these mutations contribute to carcinogenesis, and cause transformation of cells in association with the PI3K/AKT pathway ${ }^{(9-11)}$. Some studies have previously emphasized the potential prognostic significance of loss of ARID1A expression in various predominantly gynecological malignancies ${ }^{(9)}$. Various studies have also emphasized potential prognostic significance of loss of ARID1A expression in gastric carcinomas ${ }^{(9-11)}$.

Our aim is to examine the relationship between ARID1A expression with clinicopathological parameters in cases with gastric carcinomas so as to investigate the potential role of ARID1A as a target marker in the treatment of gastric carcinoma.

\section{MATERIAL and METHODS}

The gastrectomy specimens of all patients who were diagnosed and treated in Tepecik Research and Training Hospital between 2011 and 2014 were included in this study. Demographic data including age, and gender of the patients, and medical information including tumour location, diameter and TNM stage of the tumour in 113 cases with gastric carcinoma were retrospectively evaluated. All cases were also investigated in terms of type, and grade of the tumor, lymphovascular, and perineural invasion, and lymph node involvement. This study was approved by the local Ethics Committee.

The paraffin block most suitable for immunohistochemical evaluation was selected, and labeled firstly on the slide, and then the block was labeled, and 2 mm-diameter cylindrical tissue samples were harvested from donor blocks. Then microarray blocks

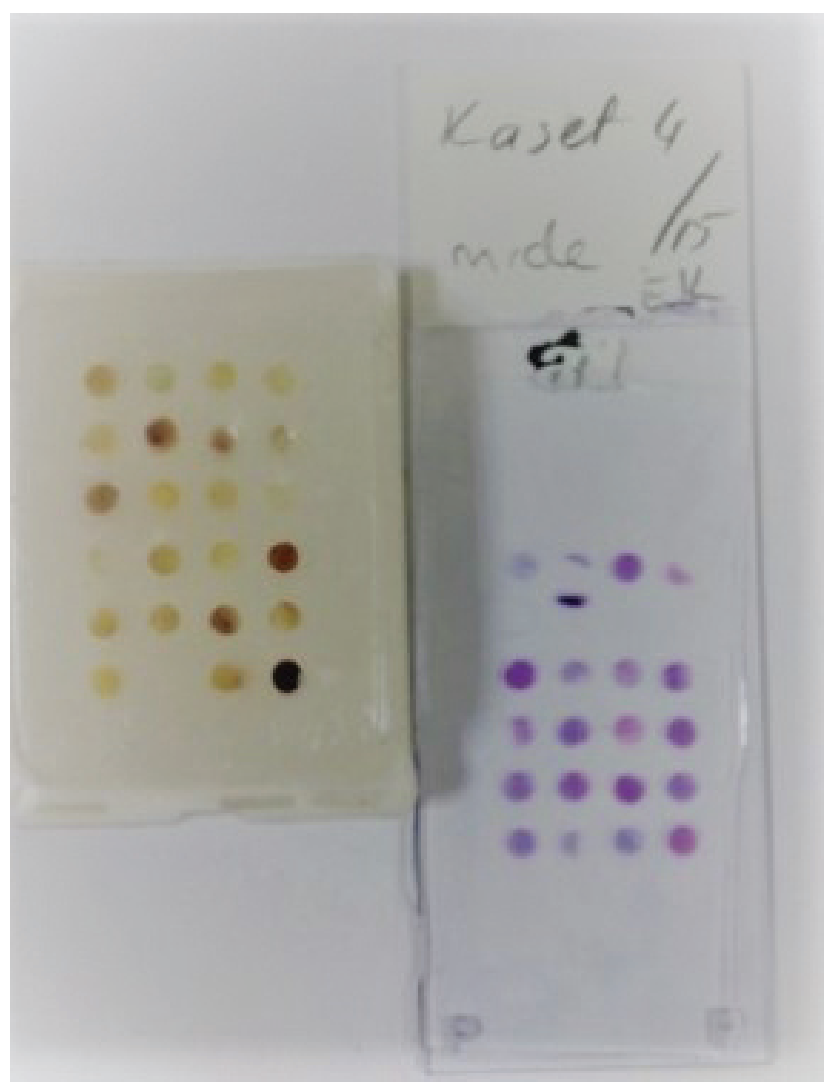

Figure 1. The microarray block and slide. 
were prepared using mapping, and addressing techniques (Figure 1).

From each prepared block, 2 different tissue samples from placenta, and spleen were used for the purpose of addressing. Sections retrieved from prepared blocks were either stained with H\&E or immunohistochemically $(\mathrm{IHC})$ stained with primer antibody of ARID1A (polyclonal, Sigma, 1/200 dilution, catalogue \#: HPA005456). For IHC staining, sections were placed on lysine coated slides, and subjected to deparaffinisation procedure for 1 hour in an incubator. Afterwards slides were immersed in hot $\left(65^{\circ} \mathrm{C}\right)$ citrate solution $(\mathrm{pH}: 6.0)$ for 20 minutes in DAKO PT LINK device. Slides were left to cooling in the buffer solution for 5 minutes. Then using avidin- biotin methods, the slides were treated with primer antibody at $1 / 200$ dilution and left under room temperature. Stromal cells, lymphocytes, fibroblasts, and endothelial cells displayed positive nuclear staining, and used as positive internal control (Figure 2). Immunohistochemically stained sections for ARID1A were examined under light microscope.

In the assessment of immune reactivity for ARID1A,

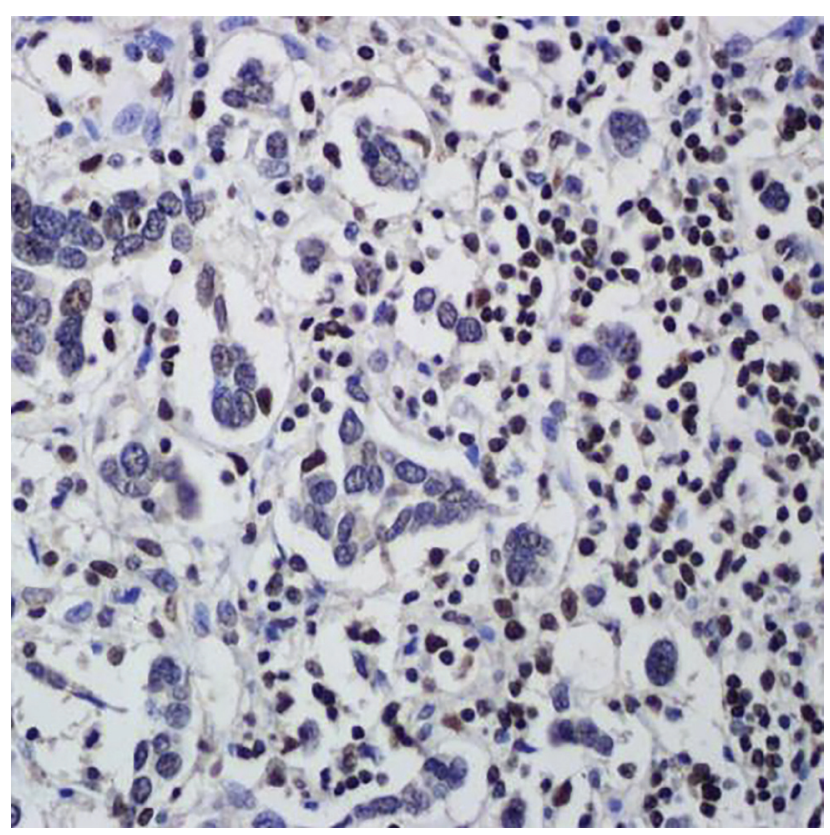

Figure 2. Loss of ARID1A expression. Note the presence of ARID1A expression in lymphocytes (DABx400). percentage, and intensity (mild, moderate, strong) of nuclear staining in the tumoral area were evaluated (Figure 3). Different cut- off values were used in previous studies to evaluate the loss of ARID1A. Normally, all nuclei of normal tissues and tumours show strong and diffuse ARID1A expressions. We did not use a threshold value for ARID1A because of uncertainties about the accurate cut-off value.

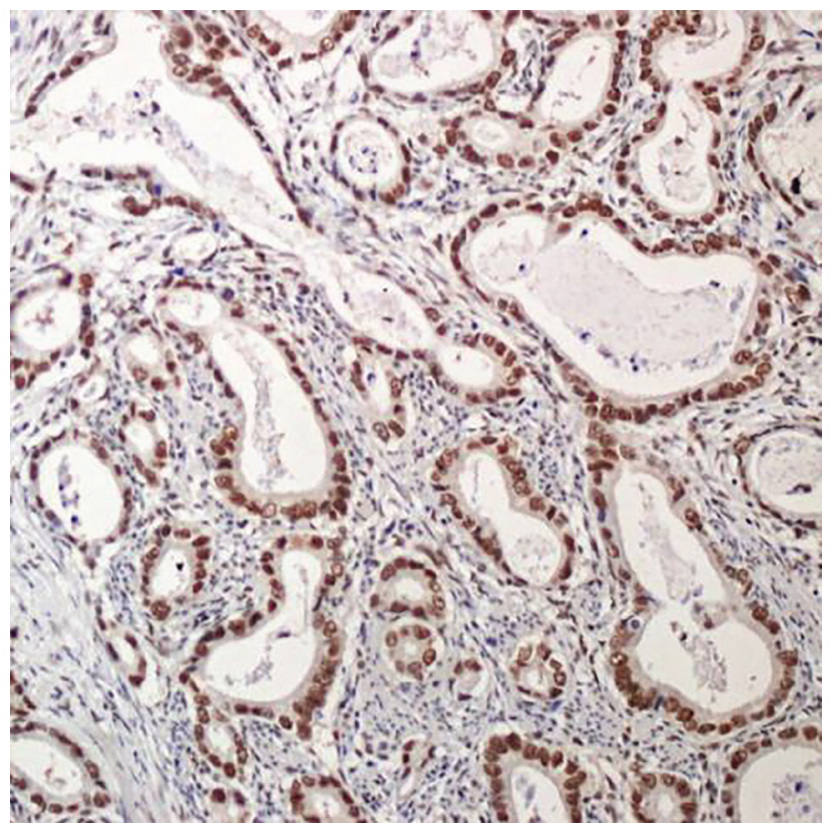

Figure 3. Moderate ARID1A expression (DABx100).

For IHC staining, primer antibody of CerbB2 (DAKO, A0485, ready to use) and for FISH analysis, HER2 IQ FISH pharmDx Kit (DAKO) were used. Technical procedures were applied according to the manufacturer's data sheets. In IHC evaluation of strong complete, basolateral or lateral membranous staining detected in more than $10 \%$ of cells was rated as score $3+$, and only $3+$ cases were considered as CerbB2-positive cases. Two and three positive cases with IHC were confirmed by fluorescence in situ hybridization (FISH). CerbB2 immunohistochemical staining and HER2 amplification were scored according to ASCOCAP guidelines.

In the statistical analysis, for the comparison of the categorical variables chi-square test was used. For the comparison of the continuous variables in 2 gro- 
ups Student's T, and Mann-Whitney $U$ tests, in more than 2 groups Kruskal-Wallis test were utilized. For the correlation of 2 continuous variables Pearson Correlation analysis was used. $\mathrm{P} \leq 0.05$ was accepted as the level of significance.

\section{RESULTS}

In this study 113 gastrectomized patients with gastric carcinoma were evaluated. The study population consisted of 75 male (66.4\%), and 38 (33.6) female patients with an overall mean age of $64.2 \pm 12.5$ years (age range, 36-92 years). The gastric carcinomas were localized on cardia ( $n=23 ; 20.4 \%)$, corpus ( $n=47$ $(41.6 \%)$, and antrum/ pylorus in $43(38.1 \%)$ cases. Dimensions of the tumours ranged from 0.8 to $15 \mathrm{~cm}$ (mean, $6.3 \pm 3.1 \mathrm{~cm}$ ). Their histopathological subtypes consisted of poorly cohesive $(n=54)$, tubular $(n=44)$, mucinous $(n=4)$, papillary types $(n=2)$ adenocarcinomas, and mixed type $(n=9)$. Local lymph node metastasis was detected in 90 cases. Based on TNM classification, the cases were evaluated in categories of pT4 (n=12), pT3 (n=83), pT2 (n=9), pT1b (n=9), N0 $(n=23), N 1(n=16), N 2(n=26), N 3 a(n=28)$, and N3b $(n=20)$. Distant organ metastases were observed in 35 cases, while in 78 cases any metastasis was not seen. Metastases were localized in liver $(n=16)$, lungs $(n=11)$, peritoneum $(n=6)$, and ovaries $(n=2)$. Thirtyone (27.4\%) HER2-positive tumours were detected using FISH and/or IHC analyses.

The mean percentage of ARID1A-stained cells was $55.42 \%$ (min. 1\%, and max. 100\%) (Table 1). ARID1A expression was found in respective percentages of pT1b (73.89\%), pT254 (22\%), pT3 (53,76\%), and pT4

Table 1. Descriptive results of percentage of ARID1A stained cells.

\begin{tabular}{lc}
\hline Percentage of ARID1A stained cells & \\
\hline Mean & $55.42 \%$ \\
Median & $70.00 \%$ \\
Standart Deviation & $33.70 \%$ \\
Minimum & $1.00 \%$ \\
Maximum & $100.00 \%$ \\
$25^{\text {th }}$ percentile & $30.00 \%$ \\
$75^{\text {th }}$ percentile & $90.00 \%$
\end{tabular}

(53.92\%) tumours (Figure 4). These results were not statistically significant $(p=0.219)$. ARID1A expression was detected in indicated percentages of poorly cohesive $(56.61 \%)$, tubular (48.52\%) mucinous (80\%), papillary $(73.75 \%)$ and mixed (76.25\%) type tumours without any statistically significant intergroup difference $(p=0.093)$. ARID1A expression was found in $56.52 \%$, $53.98 \%$, and $56.40 \%$ of the tumours localised in cardia, corpus and pylorus, respectively without any statistically significant intergroup difference $(p=0.978)$. ARID1A expression was found in indicated percentages of tumours with lymph node metastasis $55.87 \%$, $53.65 \%$ in tumours with no lymph node metastasis $(p=0.780)$. ARID1A expression was found in tumours with, and without lymphovascular invasion $(53.87 \%$ vs $59 \%)(p=0.461)$. ARID1A expression was found $53.04 \%$ in tumours with perineural invasion, $59.59 \%$ in tumours with no perineural invasion $(p=0.323)$. ARID1A expression was also found in HER2-positive, and negative tumours (61.23\% vs $53.22 \%)(p=0.262)$ without any statistically significant difference.

Median tumour diameters were $7.29 \mathrm{~cm}$ and 5.87

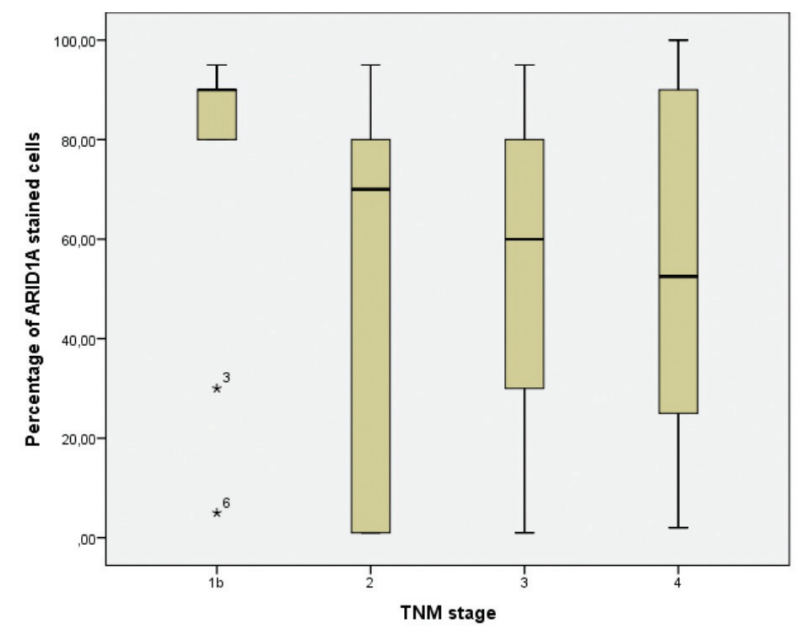

Figure 4. The percentage of ARID1A stained cells according to TNM stage.

Table 2. Mortality percentages according to TNM stages.

\begin{tabular}{lccccc}
\hline \multirow{2}{*}{ TNM Stage } & \multicolumn{3}{c}{ Mortality } & & \multicolumn{2}{c}{ Total } & \\
\cline { 2 - 3 } Number of cases & $\%$ & & Number of cases & p value \\
\hline Early (T1b, T2) & 3 & 16.7 & & 18 & 0.019 \\
Advance (T3, T4) & 44 & 46.3 & 95 & &
\end{tabular}


$\mathrm{cm}$ in cases with and without distant organ metastases, respectively. The relationship between distant organ metastasis, and tumour size was statistically significant ( $p: 0.027)$.

Average mortality rates in advanced (T3, and T4), and early stage (T1b, and $\mathrm{T} 2$ ) cases were $46.3 \%$, and $16.7 \%$, respectively. The relationship between $\mathrm{pT}$ stage, and mortality was statistically significant (p:0.019) (Table 2).

Distant organ metastases were seen in $25.6 \%$ of HER2 negative cases, and $45.1 \%$ of HER2 positive cases with a statistically significant intergroup difference ( $p: 0.045)$.

\section{DISCUSSION}

Prognostic value of HER2 amplification in gastric carcinomas is debatable. In some studies HER2 expression was found to be correlated with shorter survival, however especially recent studies have not confirmed its prognostic value ${ }^{(7,9,12-16)}$. HER2 expression is associated with poorly differentiated tumours, and lymph node metastases ${ }^{(9)}$. In our study $48.3 \%$ of HER2-positive tumours were poorly differentiated. However a statistically significant difference was not found between HER2-positive, and negative tumours in terms of age, gender of the patients, histological subtypes, lymph node metastases, pT, and N stages, lymphovascular, and perineural invasion. We think that our data contradicting literature findings are related to the non-randomized design of our series, higher number of HER2-positive tumours, and heterogeneous distribution of the cases. In our study $35.5 \%$ of HER2-positive, and $47.6 \%$ of HER2-negative patients died secondary to gastric cancer. According to our results, a statistically significant difference between HER2 status, and mortality was not found.

It was demonstrated that the presence of mutation on ARID1A gene is strongly associated with loss of ARID1A expression. Mutations, and deficient expres- sion of ARID1A protein are quiet frequently encountered in ovarian, and uterine carcinomas, and also in a significant number of cases with gastric carcinoma (17). Decrease in ARID1A expression has been associated with poor prognosis, and metastatic disease ${ }^{(10)}$. A significant relationship was found between worse clinical course, and loss of ARID1A expression. Loss of ARID1A expression in gastric cancer is associated with more malignant phenotypes and is associated with a worse prognosis, which may play a tumor suppressor role in gastric carcinogenesis ${ }^{(11)}$.

We reviewed small number of studies performed on this subject. Detected rates of ARID1A expression were lower when scoring was based on intensity of staining. However, relatively increased loss of ARID1A expression was observed when scoring was based on the percentage of stained nuclei. We attributed this diversity between assessments to lack of established consensus on the evaluation of loss of ARID1A expression, and staining ${ }^{(18-20)}$.

In a study by Wiegand et al. ${ }^{(9)}$ a significant correlation was not found between loss of ARID1A expression, and HER2 amplification. In our study, loss of ARID1A expression in HER2 negative cases was more than HER2 positive group. However in accordance with literature findings it did not differ statistically significantly between HER2 negative, and positive groups.

In a cohort study performed in 2014 in two centers a correlation was not found between loss of ARID1A expression, and any one of the clinical parameters ${ }^{\left({ }^{9}\right)}$. In our study, a statistically significant correlation was not found between loss of ARID1A expression, age, gender of the patients, location, size, histological subtype, $\mathrm{pT}$, and $\mathrm{N}$ stage of the tumor.

ARID1A has a prognostic value in early stage gastric carcinomas ${ }^{(9)}$. Loss of ARID1A expression has a lesser prognostic value in cases with adverse clinicopathological findings as advanced stage, and proximally localized tumor ${ }^{(9)}$. Wang et al. ${ }^{(11)}$ also showed the presen- 
ce of a statistically significant correlation between the loss of ARID1A expression and worse clinical outcome of gastric cancer patients after radical operation. Cox hazard ratio regression analyzes showed that; ARID1A expression is an independent risk factor for survival, and may be a valuable prognostic biomarker for postoperative gastric cancer patients and a potential target for gene therapy in the treatment of gastric cancer. In ovarian clear cell carcinoma, patients with positive ARID1A expression have been reported to have longer progression-free survival than those with ARIDIA-negative cases. In clear cell carcinoma of the ovary, loss of ARID1A expression is associated with chemoresistance and poor prognosis. Taken together, the loss of ARID1A expression in gastric cancer is associated with more malignant phenotypes and is associated with a worse prognosis, which may play a tumor suppressor role in gastric carcinogenesis ${ }^{(9,11,21)}$. In the current study, we also found a statistically significant association between loss of ARID1A expression and survival. Similar to the previous reports, the overall survival in HER2-negative gastric carcinomas was significantly reduced in cases with loss of ARID1A expression ${ }^{(9,11,21)}$.

Gastric carcinomas are usually diagnosed at their advanced stages, and patients have a short survival time ${ }^{(18-20)}$. Therefore in gastric tumours in addition to histopathological diagnosis, molecular classification is also important as in the case with breast tumors. It was previously reported that HER2 amplification has prognostic and therapeutic significance in gastric carcinomas. In fact, HER2-negative cases have a better prognosis even if not treated. However survival of HER2-positive cases treated with a thyrosine kinase inhibitor is better ${ }^{(9)}$. In our study, we tried to emphasize that in some cases HER2 amplification plays a role in carcinogenesis, however in HER2negative cases, ARID1A gene may have an important place in carcinogenesis. As we have found in our study, a statistically significant correlation between ARID1A expression, and survival is indicative of the above mentioned correlations.
Some recent studies have demonstrated an interdependency of ARID1A and the PI3K/AKT pathways, which results in significantly increased sensitivity of ARID1A-deficient cancer cells to PI3K/AKT inhibitors such as PIK3IP1 ${ }^{(20)}$. Because of the presence of clinically applicable p53-stabilizers and PI3K/AKT inhibitors; ARID1A will not be only a useful biomarker, but also it will be a useful therapeutic target ${ }^{(20,22)}$.

This study is constrained by a few limitations including restricted number of cases, nonhomogenous distribution of HER2 positive and negative cases.

In conclusion, development of appropriate biomarkers which both predict the course of the gastric cancer, and lead to the application of targeted therapies with resultant decrease in mortality rates will facilitate prediction of treatment outcomes in gastric cancer ${ }^{(20)}$. Expression of ARID1A seems to be a promising marker in the prediction of the prognosis of gastric cancer. Besides, several targeted drugs have been developed for the treatment of ARID1A- mutated cancers. However expression of ARID1A in gastric carcinomas should be investigated in larger series.

Ethics Committee Approval: Izmir Tepecik Training and Research Hospital Local Ethics Committee approval was obtained (2015).

Conflict of Interest: The authors declare that they have no conflicts of interest.

Funding: There is no institution that provides financial support to our study. The authors covered the cost.

Informed Consent: Informed consent was obtained from patients who could be reached by telephone.

Etik Kurul Onayı: İzmir Tepecik Eğitim ve Araştırma Hastanesi Yerel Etik Kurul onayı alınmıştır (2015).

Çıkar Çatışması: Yazarlar çıkar çatışması olmadığını beyan ederler.

Finansal Destek: Çalışmamıza finansal destek sağlayan bir kuruluş yoktur. Masrafı yazarlar karşılamıştır.

Hasta Onamı: Telefonla ulaşılabilen hastalardan onam alınmıştır. 


\section{REFERENCES}

1. Howson CP, Hiyama T, Wynder EL. The decline in gastric cancer: epidemiology of an unplanned triumph. Epidemiol Rev 1986;8:1-27. Review. PubMed PMID: 3533579. [CrossRef]

2. Kramer BS, Johnson KA. Other gastrointestinal cancers stomach, liver. In Greenwald P, Kramer BS, Weed DL. (eds) Cancer Prevention and Control. Marcel Dekker, New York NY, 1995 pp. 673-94.

3. O' Connor F, Buckley M, O' Morain C. Helicobacter pylori: the cancer link. J R Soc Med. 1996;89(12):674-8. [CrossRef]

4. Cover TL, Blaser MJ. Helicobacter pylori: a bacterial cause of gastritis, peptic ulcer disease, and gastric cancer. Am Soc Microbiol News. 1995;61:21-6.

5. Genta RM, Rugge M. Assessing risks for gastric cancer: new tools for pathologists. World J Gastroenterol 2006;12(35):5622-7. Review. PubMed PMID: 17007013; PubMed Central PMCID: PMC4088161. [CrossRef]

6. Vieth M, Stolte M. Elevated risk for gastric adenocarcinoma can be predicted from histomorphology. World J Gastroenterol 2006;12(38):6109-14. Review. PubMed PMID: 17036380; PubMed Central PMCID: PMC4088102. [CrossRef]

7. Gomez-Martín C, Lopez-Rios F, Aparicio J, Barriuso J, GarcíaCarbonero R, Pazo R, et al. A critical review of HER2-positive gastric cancer evaluation and treatment: from trastuzumab, and beyond. Cancer Lett 2014;351(1):30-40. Epub 2014 Jun 3. Review. PubMed PMID: 24943493. [CrossRef]

8. Sheffield BS, Garratt J, Kalloger SE, Li-Chang HH, Torlakovic $E E$, Gilks $C B$, et al. HER2/neu testing in gastric cancer by immunohistochemistry: assessment of interlaboratory variation. Arch Pathol Lab Med 2014;138(11):1495-502. PubMed PMID: 25357111. [CrossRef]

9. Wiegand KC, Sy K, Kalloger SE, Li-Chang H, Woods R, Kumar A, et al. ARID1A/BAF250a as a prognostic marker for gastric carcinoma: a study of 2 cohorts. Hum Pathol 2014;45(6):125868. Epub 2014 Feb 20. PubMed PMID: 24767857. [CrossRef]

10. Yan $H B$, Wang $X F$, Zhang $Q$, Tang $Z Q$, Jiang $Y H$, Fan $H Z$, et al. Reduced expression of the chromatin remodeling gene ARID1A enhances gastric cancer cell migration and invasion via downregulation of E-cadherin transcription. Carcinogenesis 2014; 35(4):867-76. Epub 2013 Nov 30. PubMed PMID: 24293408. [CrossRef]

11. Wang DD, Chen YB, Pan K, et al. Decreased expression of the ARID1A gene is associated with poor prognosis in primary gastric cancer. PLoS One 2012;7(7):e40364. Epub $2012 \mathrm{Jul}$ 13. PubMed PMID: 22808142; PubMed Central PMCID: PMC3396657. [CrossRef]

12. Tanner $M$, Hollmén $M$, Junttila TT, Kapanen Al, Tommola $S$, Soini $Y$, et al. Amplification of HER2 in gastric carcinoma: Association with Topoisomerase Ilalpha gene amplification, intestinal type poor prognosis and sensitivity to trastuzumab. Ann Oncol 2005;16(2):273-8. PMID: 15668283.

\section{[CrossRef]}

13. Park DI, Yun JW, Park JH, Oh SJ, Kim HJ, Cho YK, et al. HER-2/ neu amplification is an independent prognostic factor in gastric cancer. Dig Dis Sci 2006;51(8):1371-9. Epub 2006 Jul 26. PubMed PMID: 16868827. [CrossRef]

14. Gravalos C, Jimeno A. HER2 in gastric cancer: a new prognostic factor and a novel therapeutic target. Ann Oncol 2008;19(9):1523-9. Epub 2008 Apr 25. Review. PubMed PMID: 18441328. [CrossRef]

15. Gómez-Martin C, Garralda E, Echarri MJ, et al. HER2/neu testing for anti-HER2-based therapies in patients with unresectable and/or metastatic gastric cancer. J Clin Pathol 2012; 65(8):751-7. Epub 2012 May 8. PubMed PMID: 22569536; PubMed Central PMCID: PMC3410298. [CrossRef]

16. Janjigian YY, Werner D, Pauligk C, Steinmetz K, Kelsen DP, Jäger $E$, et al. Prognosis of metastatic gastric and gastroesophageal junction cancer by HER2 status: a European and USA International collaborative analysis. Ann Oncol 2012;23(10):2656-62. Epub 2012 Jun 11. PubMed PMID: 22689179. [CrossRef]

17. Abe H, Maeda D, Hino R, Otake $Y$, Isogai M, Ushiku AS, et al. ARID1A expression loss in gastric cancer: pathway-dependent roles with and without Epstein-Barr virus infection and microsatellite instability. Virchows Arch 2012;461(4):367-77. [CrossRef]

18. Han N, Kim MA, Lee HS, Kim WH. Loss of ARID1A Expression is Related to Gastric Cancer Progression, Epstein-Barr Virus Infection, and Mismatch Repair Deficiency. Appl Immunohistochem Mol Morphol 2016;24(5):320-5. PubMedPMID:26067140. [CrossRef]

19. Inada R, Sekine S, Taniguchi H, Tsuda H, Katai H, Fujiwara T, et al. ARID1A expression in gastric adenocarcinoma: clinicopathological significance and correlation with DNA mismatch repair status. World J Gastroenterol 2015;21(7):2159-68. PubMed PMID: 25717252; PubMed Central PMCID: PMC4326154. [CrossRef]

20. Ayaz D, Diniz G, Kahraman DS, Sayhan S, Uncel M, Karadeniz $\mathrm{T}$, et al. The evaluation of the caveolin-1 and AT-rich interactive domain 1 alpha expressions in uterine smooth muscle tumors. Indian J Pathol Microbiol 2016;59(3):301-4. PubMed PMID: 27510664. [CrossRef]

21. Yamamoto $H$, Watanabe $Y$, Maehata $T$, Morita R, Yoshida $Y$, Oikawa R, et al. An updated review of gastric cancer in the next-generation sequencing era: insights from bench to bedside and vice versa. World J Gastroenterol 2014;20(14):392737. Review. PubMed PMID: 24744582; PubMed Central PMCID: PMC3983448. [CrossRef]

22. Bitler BG, Fatkhutdinov N, Zhang R. Potential therapeutic targets in ARID1A-mutated cancers. Expert Opin Ther Targets 2015;19(11):1419-22. Epub 2015 Jun 30. Review. PubMed PMID: 26125128; PubMed Central PMCID: PMC4674066. [CrossRef] 